\title{
The Ethnic Culture Page IN MEDAN JOURNALISM
}

\author{
Susan Rodgers
}

North Sumatra's abundant print culture has long served the region's ethnic societies as a kind of grand concourse of public communication for defining community character and history. The province's schoolbooks, novels, adat guides, clan histories, ethnic group histories, tourist pamphlets, ${ }^{1}$ and newspapers have provided North Sumatran writers from Malay, Javanese, Niassian, Acehnese, Minangkabau, and especially various Batak backgrounds with ready media forms for presenting the region's ethnically diverse cultures to several audiences. These include readers from the individual authors' own ethnic societies as well as larger national audiences (i.e., members of distant ethnic societies, city readers close to the cosmopolitan national culture, or readers from the national government itself). These national audiences can encounter North Sumatran ethnic cultures via the printed word when Indonesian, rather than a local ethnic language such as Toba Batak, is used as the medium of description. With the exception of some adat guides and clan histories, most North Sumatran attempts to "write ethnic cultures" are indeed in the national language. This has been the case throughout the national period.

\footnotetext{
${ }^{1}$ Some of these publications for the Southern Batak society of Angkola are discussed in Susan Rodgers, "A Batak Literature of Modernization," Indonesia 31 (April 1981): 137-62; idem, "Orality, Literary, and Batak Concepts of Marriage Alliance," Journal of Anthropological Research 40 (3) (Fall 1984): 433-50; idem, "Batak Tape Cassette Kinship: Constructing Kinship through the Indonesian National Mass Media," American Ethnologist 13 (1) (1986): 2342; and idem, "A Sumatran Antiquarian Writes His Culture: Print Literacy and Social Thought in an Indonesian Society," Journal of the Steward Anthropological Society 17 (1/2) (1987-88): 99-121. Representative publications of each type are, in order, Soetan Martoewa Radja, Doea Sadjoli, (Batavia: Landsdrukkery, 1919); M. J. St. Hasoendoetan, Sitti Djaoerah, 2 vols. (Sibolga: Philemon bin Haroen, 1927-1929); Sutan Tinggi Barani Perkasa Alam, Dra. Rukiah Siregar, and Paruhumon Harahap, Burangir na Hombang (Padangsidimpuan: Privately published, 1977); Sutan Habiaran Siregar, and O. Gorga Torsana, Toga Siregar (Medan: Privately published, 1974); and Ismail Manalu, S.H., Mengenal Batak (Medan: C. V. Kiara, 1985).

Southern Batak and Toba folkloristic treatments of Batak village culture were being published in some abundance by the 1920s, when these areas had thriving local newspapers and a constant demand for elementary school texts in Batak languages. There has been a pronounced increase in Batak culture works during the last fifteen years directed especially to urban migrant audiences in Medan and Jakarta. H.M.D. Harahap, Adat Istiadat Tapanuli Selatan (Jakarta: Grafindo Utama, 1986) is typical of these books: slickly produced, erudite and educational in tone, and claiming special access to "ancient knowledge."
} 
In this article I offer a reading of one form of contemporary, predominantly Indonesianlanguage newspaper writing from North Sumatra's capital city of Medan: a weekly feature page on ethnic cultures and peoples that appears in many of the city dailies such as Sinar Indonesia Baru (SIB) and Waspada. I shall be looking at this type of journalism as a form of political discourse. On the "ethnic culture page" (as this section of the paper is known), North Sumatran writers located at various points within ethnic and national political worlds attempt to set down those symbolic universes ("Toba Culture," "Toba Batak Culture in Multiethnic Indonesia") in prose and provide them with histories, typical social organizational forms, and cultures. The latter is usually construed in contemporary North Sumatran journalism to mean "old ethnic ways" in a folkloristic sense. Writing of this sort involves a large-scale invention of traditions, as well as many resourceful attempts to situate "ancient village cultures" within a "more modern" Indonesian national framework. Different types of writers imagine quite different ethnic worlds on the ethnic culture page. This situation makes this form of journalism one of the most volatile arenas of Indonesian political thought open to study.

\section{Writing Cultures in Cosmopolitan North Sumatra}

As background to an examination of one Medan daily's ethnic culture page, one can look first to more general issues of constructing ethnicity in Indonesia through print. The newspaper I shall consider is Sinar Indonesia Baru, ${ }^{2}$ the city's most energetic booster of North Sumatran "ancient heritages." SIB is also a tireless proponent of Indonesian nationalism and national economic development. The paper is both Toba Batak in tone and Indonesian in conceptual scope. The sorts of political communication SIB fosters in this regard are part of larger systems of literature extending beyond journalism.

Because the national language brings North Sumatran-authored literatures a sociologically broad audience and because many media forms are subject to national government licensure and censorship, the imagery of ethnic customs and heritages used by local authors has often been constructed in tight interaction with the powerful culture-defining institutions of the nation itself. ${ }^{3}$ Today, these include Indonesia's public school system; the Ministry of Education and Culture's local history projects; the national television station's "ethnic peoples" programs; and various patriotic endeavors such as the identification and

\footnotetext{
2 I draw my material from a set of clippings I collected from SIB during my fieldwork in Sumatra (July 1974February 1977; December 1980; April-August 1983; September 1986-March 1987; June-August 1989). An elderly Sipirok woman also provided me with other issues because she was saving old papers to wrap textiles in market day in her occupation as a cloth seller. SIB is also available in the National Library in Jakarta. The paper began publication in 1974. For a discussion of SIB's role in the invention of Batak ethnic traditions via the invocation of heroic narratives such as the stories associated with the warrior-king Sisingamanga Raja XII, see Susan Rodgers, "City Newspapers in the Creation of a Batak Political Heritage," in Cultures and Societies of North Sumatra, ed. Rainer Carle (Berlin: Dietrich Reimer Verlag, Band 19, Veroffentlichungen des Seimnars fur Indonesische und Sudseesprachen der Universitat Hamburg, 1986), pp. 198-200. In this article, I look at ethnic culture coverage throughout the entire paper not just the ethnic culture page and focus on the paper's concentration on the "ancient culture" activities of its general manager, the Toba Batak G. M. Panggebean.

${ }^{3}$ For additional discussion of this point, see Benedict Anderson "Cartoons and Monuments: The Evolution of Political Communication under the New Order," in Political Power and Communications in Indonesia, ed. Karl D. Jackson and Lucian W. Pye (Berkeley: University of California Press, 1978), pp. 228-321. Anderson's earlier essay "The Languages of Indonesian Politics," Indonesia 1 (1966): 89-115, also made the productive point that much Indonesian political communication goes on outside the expected sources of official speeches and government communiqués. Leslie Palmier, "Mass Media Exposure of Indonesian Graduate Officials," Indonesia 44 (1987): 117-28, details which Jakarta newspapers college graduate government officials tend to read regularly; I know of no similar research on government officials' media habits in North Sumatra.
} 
promotion of national heroes from different ethnic societies. ${ }^{4}$ Throughout all forms of the print media, North Sumatran-authored descriptions of local ethnic worlds are often written with a keen awareness of the national government's agenda for accepting or rejecting particular constructions of ethnicity in the Outer Island provinces beyond Java. Javanese and Balinese high-court cultures seem to set the standards for "refined civilization" in many North Sumatran statements about local ethnic worlds, but many writers manage to find local Batak "equivalents" for such things as Javanese gamelan orchestras or batik textiles.

No Batak effort to write Batak culture, however, has totally free poetic license. The central government's constraints on the processes of inventing ethnic cultures in provinces such as North Sumatra are well illustrated in the Ministry of Education and Culture's Proyek Inventarisasi dan Dokumentasi Kebudayaan Daerah (or, Project for the Inventory and Documentation of Local Cultures). This ambitious project ${ }^{5}$ sought to inventory and record ethnic ways in all of the nation's major local societies and then publish and distribute descriptive accounts of them to public libraries throughout the archipelago. Typically, the volumes in this series dealt with Outer Island ethnic societies in terms of their village adat rituals, children's games, old sayings, colorful clothing, and folk dances. Construed in this antiquarian way, Indonesia's Outer Island ethnic cultures emerged in these government publications as quaint collections of mildly diverting ancient customs and oral literature forms suitable for the leisure time contemplation of urban sophisticates of "more modern" national identity.

This flaccid formulation of local ethnic cultures is not the only one available in North Sumatra, however. The national government's publications must compete there with a wide range of other, often much more engagingly written works dealing with the same subjects. The Ministry of Education and Culture's folkloristic vision of ethnic cultures is counterposed to a more politically robust version of ethnic heritages, promoted, for instance, in such writing genres as Batak adat guidebooks, clan genealogies, and proverb samplers. North Sumatran ethnic societies appear in many printed works of this sort as heirs of long, highly refined village governmental traditions. These traditions are based (according to these accounts) on sturdy marriage alliance and clanship foundations (which other Indonesian cultures, such as that of Java, do not have), whose genius predates the Indonesian nation.

There are many Batak works of this sort, ${ }^{6}$ apparently written in careful dialogue with alternative visions of ethnic cultures that have been conceived closer to the center of Indonesian national culture. When considered in the most general sense, in fact, much North Sumatran writing about ethnic group societies and histories is part of a massive communications effort to negotiate the terms of the province's social imagery with writers speaking for

\footnotetext{
4 Janet Hoskins, "The Headhunter as Hero: Local Traditions and Their Reinterpretation in National History," American Ethnologist 14 (4) 1987: 605-22, to be discussed in the conclusion, offers an acute political analysis of local ethnic minority societies' attempts to turn the national government's glorification of national heroes to local benefit.

${ }^{5}$ From the late 1970s through the mid-1980s, this large project of the Ministry of Education and Culture sought to commission a full roster of descriptive works for each province. These publications are sometimes available in the public libraries of provincial capitals and in ministry offices at the provincial and subprovincial libraries; the Library of Congress also has numerous titles in this series.

6 Susan Rodgers, "Batak Heritage and Indonesian State: Print Literacy and the Creation of Ethnic Cultures in Indonesia," in Ethnicity and the State, ed. Judith Toland, Volumes in Political Anthropology (New Brunswick, N.J.: Transaction Press, Forthcoming) discusses the southern Batak adat guidebook literature in the context of the national government's ethnic culture publications.
} 
Indonesian national culture. This situation of political competitiveness and energetic imagemaking has meant that North Sumatran writers' many efforts to write their ethnic cultures have been particularly creative and quick-changing. Perhaps this helps explain why the Batak societies have produced a disproportionate number of fiction and nonfiction writers since the 1920 s. $^{7}$ The situation has also left this literature full of intriguing texts for anthropologists and historians interested in studying how contemporary minority societies in Indonesia are inventing traditions and worlds of ancient custom for themselves at a time when provinces like this one are being drawn with increasing finality under the national culture's canopy.

North Sumatran newspaper journalism is located at a crucial crossroads of this national culture/ethnic culture interaction. ${ }^{8}$ An area of intense city newspaper competition since the second decade of the twentieth century (when commercial papers tied to the plantation economy in Deli cultivated audiences of newly arrived Batak migrants), the province today supports at least three daily newspapers. ${ }^{9}$ All are published in Medan, in the Indonesian language, and are distributed through street sales and subscription services from Aceh to Medan through the Batak rural home regions and southward to Mandailing.

Continuing a heritage of ethnic culture coverage that dates to the 1920s, these papers give considerable play to such items as Toba Batak adat feasts, notices of Simelungun Batak funerals, and ethnic culture fairs such as Medan Fair (an annual theme park and ethnic culture display held at the city fairgrounds with booths for each ethnic culture in the province). These papers also offer their readers daily doses of scandalous tidbits about such things as marriages that violate clan incest rules and village diviners who take sexual advantage of their female clients. Such articles on adat matters appear alongside stories on national economic development projects, Jakarta's Five-Year Plans, and Pancasila democracy. Reporters and editors (who in these Medan newspapers are often Batak themselves) are clearly engaged in the promotion of a social universe in which "ancient ethnic cultures" (those of Toba, Angkola, Simelungun, Karo, Nias) thrive alongside-or, more accurately, inside-a larger, purportedly more modern Indonesian sphere. Other writers for the ethnic culture page-who tend to be special contributors not regular staff-describe and praise more independent ethnic entities.

Most Medan newspapers have a strong Batak flavor, reflecting the province's overwhelming Batak majority population. But, as noted, these same papers also maintain a consistently patriotic, pronational development slant. In this context, Batak village adat heritages and Batak cultural richness are the main symbolic currencies for Medan newspaper discussions of ethnicity and ethnic culture/national culture issues. Indonesia will modernize more smoothly, in this view, if the nation can conserve and cultivate its many old ethnic heritages. This interpretation of national development gives Medan newspaper

\footnotetext{
7 The Toba, Angkola, and Mandailing Batak cultures include the following writers: Armijn Pane, Sanusi Pane, Mochtar Lubis, Sitor Situmorang, Parada Harahap, and Iwan Simatupang. Today, many writers from these cultures write pulp fiction for the national mass market (e.g., Sori Siregar, S. Baya, Kumpul Siregar, S.B. Chandra, Kamuluddin Lubis, and Abdullah Harahap).

${ }^{8}$ Medan's main dailies Waspada, Analisa, and SIB are available in the national library in Jakarta. Jakarta's Kompas is regularly available at Medan newstands (not always the case in the subprovincial capitals, such as Taratung and Padangsidimpuan.) Medan newstands also typically carry the larger mass circulation magazines, such as Tempo and Jakarta; several carry the English-language Time, Newsweek, and International Herald Tribune.

${ }^{9}$ Waspada, is predominantly a Muslim, southern Batak paper; Analisa has ties to Medan's large Chinese-Indonesian community; and SIB, is edited by Christian Toba Batak management for as large and heterogeneous a North Sumatran readership as possible.
} 
editors an opening for glorifying the Batak village past, which also leads them to invite special contributors to write essays on Toba Batak funerals, Nias stonework, Karo traditional dances, and so on. Because the central government's Ministry of Communication exerts censorship control over these Medan newspapers ${ }^{10}$ (and because editors evidently feel obliged to promote the government's economic development plans by displaying propagandistic slogans on their front pages) ethnic discourse in these papers has become a continual series of bargains executed along the social boundary joining the province's ethnic communities to the Indonesian nation. It is the implicit political tension in this situation that makes Medan newspaper writing as contentious and boisterous as it is.

\section{Ethnic Culture on the Feature Page}

Light, entertaining "ethnic culture items" have been a staple of North Sumatran newspaper writing for seventy years. Feature story journalism, in fact, has served Batak readers as a core medium for reflecting on social life and history since the early commercial weeklies were established in Sibolga and Padangsidimpuan in the 1920s. These newspapers included Soeara Tapanoeli (from Sibolga, in Indonesian), Soeara Rakyat (from Sipirok, in Indonesian), Poestaha (Sibolga, in Angkola-Mandailing Batak), and Pertjatoeran (Sibolga, in Indonesian).11 All provided extensive coverage of Batak heritage matters alongside news items on the modern Indies. A juxtaposition of traditional culture pieces alongside items on the progressive Indies relativized Batak culture as an old-fashioned enclave within a larger, more up-todate colonial society. But-as in later Medan newspapers in the 1970s and 1980s-ethnic culture coverage did allow serious attention to the richness of village social arrangements and oratory. Most important for our theme here is the fact that Batak writers have been adept since this early period at writing their ethnic cultures within a larger social and temporal framework extending far beyond Tapanuli.

In the 1920s and 1930s, Sibolga (a mixed Angkola, Mandailing, and Toba town with easy access to Padang) developed into a thriving publishing center for books ${ }^{12}$ and the newspaper trade. Several commercial papers were published for distribution throughout Tapanuli towns; the interaction between book publishing and the newspaper business was close. For instance, reporters would also write love story novels or compose verse-form booklets for commercial sale; newspapers ran advertisements for local books as well as for national language fiction works such as the Minangkabau-authored Sitti Nurbaya and school texts. The newspapers would sometimes serialize long novels such as Sitti Djaoerah ${ }^{13}$ before they were printed as regular books. Some of this writing activity was in Angkola Batak, a small part of it was in Dutch (e.g., individual articles in some of the newspapers), and some was in Malay, soon to be adopted as Indonesia's national language.

\footnotetext{
${ }^{10}$ SIB was closed down for several weeks in 1976, ostensibly for printing an atheistic poem on its youth page.

11 Partial runs of these papers are available in the original in Jakarta's national library.

12 These books included verse narratives, Angkola Batak language novels, and Indonesian language novels. Armijn and Sanusi Pane's father, Soetan Pangoerabaan, was particularly active in Sibolga book-publishing circles after his move from Sipirok to Sibolga to edit the newspapers issued by his Tapiannaoeli publishing house.

13 This eloquent, two-volume love story novel was written in Angkola Batak by the Siporok and Siantar author M. J. St. Hasoendoetan. Excerpts from this book are translated and discussed in Susan Rodgers, "A Batak Literature of Modernization," Indonesia 31 (April, 1981): 137-61. The work is misidentified there as Soetan Pangoerabaan, Tolbok Haleon, another Angkola language prose work on similar love story and migration themes. The partial copy of Sitti Djaoerah I obtained during my 1974-1977 Sipirok fieldwork was identified by several retired schoolteachers as Tolbok Haleon before I acquired a copy of the latter from the Koninklijk Institut voor Taal-, Land-en Volkenkunde (KITLV).
} 
In the later colonial period, on the eve of the Japanese occupation of Sumatra and the national consolidation of Indonesia as a modern state, newspaper literacy was already providing educated southern Batak with a cultural mirror in which to view their own changing reflections. International styles of newspaper reporting were firmly established in Batak papers, such as Poestaha, Oetoesasn, and Soeara_Tapanoeli, by the 1920s, but the newspapers all had a pronounced Batak flavor. That is, headlines, the front page, and a story's internal organization followed standard international form (for instance, news articles would generally conform to the inverted triangle presentation of important who-what-where-when organization early in the story followed by corroborating details). A typical issue of a paper included articles on international politics, colonial government decisions, local crime news, and commercial news (coffee prices, rubber prices, etc.).

The reporters writing such stories presented themselves as objective recorders of factual information, which they were conveying to the reading public out of abstract civic interests. However, each issue of any of these papers would also have some deeply Batak aspects. For instance, editors would write long, moralistic disquisitions on adat matters that bothered them (e.g., exorbitant brideprices). Stories on unorthodox marriages, such as those within a single clan, were given concentrated play, as were acrimonious inheritance disputes where the contending parties would each claim to be correct, according to adat. Feature stories on clan history, chanted myths (as folklore), and chieftaincy news were published alongside pieces that struck a progressive note (e.g., advice columns to Batak mothers on how to raise children who would do well in school). In general, the editors of the Padangisimpuan and Sibolga newspapers presented their newspapers as beacons of modern thinking. In this stand they were aligned with Tapanuli's small professional class of clerks and schoolteachers against the old guard ( $k a u m$ tua) who supported the power of the Dutch-backed high chiefs (kepala kuria) and a rigid interpretation of old-style adat. In fact, these commercial newspapers were major media forums for creating such ideas as "ancient Batak traditions" and "strict adat" in the first place.

With national independence, most Batak newspaper publishing moved from Tapanuli commercial towns to Medan, which also came to dominate book publishing in the province. In Tapanuli, adat ceremonial activities were branded as "feudal" during the revolution and throughout the 1950s; large-scale buffalo sacrifice feasts, called horja, were rarely held during this period because they were tainted with images of aristocratic elitism. Adat ritual life went into partial eclipse in these early years of national life, and with it much Batak ethnic culture publishing also disappeared. By the early 1960s, a few aristocratic Angkola lineages were beginning, hesitantly, to reinstate horja ceremonialism. It was only with the greater economic prosperity of the first decade of the New Order, though, that adat ritual activity returned to the village, town, and city scene with vigor and unapologetic verve. The 19651975 decade was also the time when Batak ethnic heritage publishing enjoyed a renaissance. In this period, clan histories, proverb samplers, and adat custom guidebooks were written and published in some numbers in Medan as well as in smaller cities, such as Pematang Siantar and Padangsidimpuan. Sinar Indonesia Baru, first published in 1974 and clearly targeted to a wide urban and rural Batak population, quickly moved into the newly reinvigorated ethnic culture domain.

Since the mid-1970s, feature page journalism in Sinar Indonesia Baru and its competitor Waspada has become an especially intense arena for defining ethnicity and relating it to a national framework. Considerable space throughout these papers, for instance, is devoted to nonnews accounts of Toba Batak weaving work, Karo traditional house construction, Malay marriage customs, and urban ethnic heritage clubs. A staple part of these papers, further- 
more, is the ethnic wedding announcement. This generally comes complete with a posed photograph of the newlyweds dressed in their traditional ethnic nuptial costumes (since ethnic intermarriage often occurs among the urban middle class, these photographs sometimes involve a Batak bridegroom and a Malay bride, both dressed in Batak wedding costumes.) The back page of these papers frequently includes block-style funeral notices written in Batak languages announcing the death of the aged mother or father of some prominent Medan figure from military, educational, or publishing circles. These newspapers have been printing such stories and announcements in part as a marketing device to increase their circulation in the rural ethnic home regions. There are also large populations of urban Batak, who have been resident in Medan and Pematang Siantar for two and sometimes three generations. The papers' circulation managers may hope to play on these people's nostalgia for their rural Batak home villages to spur larger newspaper sales in cities. ${ }^{14}$

Over the same fifteen-year period, one specific type of feature page journalism in Medan has developed into a particularly rich text on ethnic imagery-the lembaran budaya, or ethnic culture page. As noted, these appear weekly in most large Medan dailies, placed five or six pages back in the issue (Medan papers tend to have about twelve pages). The ethnic culture page offers a condensed, fun to read statement of contemporary North Sumatran social thought tailored to the political realities of writing ethnic cultures in present-day Indonesia and tailored as well to international journalism's entertaining but educational feature-page format.

A typical ethnic culture page from SIB's December 4, 1976, issue ran as follows. As is always the case, the page combined print stories, line drawings, and photographs. The lead article, by guest contributor Gr. Mula Pitara Siahaan, was entitled, "It's the Conservation of Batak Adat That's Important, Its Modernization Isn't Necessary for It's Been Modern Since the Past." This combative piece took issue with the opinions of Dr. P. Sormin, a Batak Protestant minister, who had published an earlier SIB story on the same cultural affairs page entitled, "The Social Functions of the Four-House-Posts in Relation to the Three-Stones-onthe-Hearth and the Five-Saoduran in Batak Adat." This earlier account borrowed on Western social science terminology (e.g., "the fungsi sosial" or social functions of such arrangements as the Batak marriage alliance). It attempted a systematic description of Toba social structure.

The December 4 ethnic culture page continued: at the bottom center of the page was a second story called, "Dr. Liberty Manik Gives a Speech about the Batak Gong Ensemble." Inset in this laudatory article on the great worth of old Batak music was a photograph of a West German woman and two small German children seated on a polished wood floor around a partially unrolled scroll painting. The caption read, "A Painting from Tempo Doeloe." This last Indonesian phrase, in colonial-era spelling, is often used by feature page writers to mean, "the old days." The caption went on to report that "Here is a painting from the old days being shown at a culture center in Binger, West Germany. It was painted by Grandparent Wu, a 79-year-old Chinese painter who lives in Taipai." To the right of this photograph were two additional stories: "The First Toba Batak Art Festival Will Be Held in Pematang Siantar" and "The Sinaga Clan's Sacred Heirloom Barkbook Disappears from

\footnotetext{
14 Over the last several years SIB's general manager, G. M. Panggebean, has been instrumental in promoting an annual "Pesta Danau Toba" (Lake Toba Festival) in the lakeside tourist town of Prapat. SIB provides heavy coverage of the ancient Batak cultural activities associated with this festival; not incidentally, another of Panggebean's financial endeavors is a tourist agency that promotes North Sumatra's scenic beauty and cultural richness.
} 
Buntumalasang Village." This story lamented the fact that "The heirloom barkbook is about 800 years old and its value cannot be calculated in monetary terms." Readers were urged to report any information about the missing heirloom to the proper authorities. At the top of the same side of the page was another short item headed, "The Clan Geneaology of Ompu Tuan Suhut Situmorang to Be Compiled." This was an informational piece, of interest to Ompu Tuan Suhut's own descendants and to other Bataks from other clans and subsocieties (Simelungun Batak, Dairi Batak, Angkola Batak, and so on) who might be collecting (and these days, writing down) their clan histories.

Off to the left of this entry was a photograph of Renoir's painting, "La Promenade," with a caption reading, "Painting Goes for $\$ 920,000.00$ U.S." Located below this picture a final article announced, "Australian Scholar Translates Indonesian Literary Works." This piece began, "Harry Aveling, an Australian scholar who has translated a great many Southeast Asian literary works into English, has translated two (books) this year." The article, datelined Perth, went on to detail Aveling's comments about the subtleties of translating modern Indonesian prose.

This page's busy conglomeration of adat antiquarianism, high-culture items from the West, arts festivals announcements, and clan history notes is entirely typical of the genre. So too is the page's placement on the inside pages of a paper that devotes major attention to national government news, economic development reports, crime stories, and international news items taken from the wire services. These stories of "larger social scope" frame the more parochial world of adat matters on the ethnic culture page.

The aims of reporters and special contributors writing for the page should not be underestimated, however. They are attempting nothing less than to anchor ancient, genuine (asli) North Sumatran ethnic worlds to three sources of legitimacy at once: to a traditional Batak village world of purported peaceability and cultural completeness; to the beguiling economic prosperity and modernity of present-day national Indonesian life; and to the cosmopolitan international sphere, where the Batak cultures take their places among similar entities, such as West Germany, and where foreign scholars devote their careers to Batak cultural studies (Dutch adat law publications on the Batak make frequent appearances on the feature page along with occasional notes about present-day studies conducted by American anthropologists). ${ }^{15}$

How do different writers invoke these several sources of legitimacy and imagine distinctive ethnic worlds? In the 1974-1990 period of renewed Batak adat ceremonial activity, ${ }^{16}$ a common strategy among the relatively well-to-do urban Batak and their rural lineage mates was to uphold adat (through lavish feasts of merit) while supporting negara (the Indonesian nation) and agama (the two main world religions among Batak, Christianity and Islam). SIB's editors promoted strong ethnic culture coverage in this context. An examination of the imagery of history, society, and ethnic culture on the ethnic culture page will show how ambitious the paper's several groups of writers were in imagining Sumatran social diversity. These three domains also demonstrate considerable diversity of opinion.

\footnotetext{
15 Several Toba and Angkola adat guidebook and Batak history writers, such as Ompu Buntilan, G. Siregar Baumi, and Sutan Habincaran Siregar have met and helped American anthropologists with their research.

16 Permanent city dwellers return periodically to their ancestral villages in Tapanuli to sponsor lavish three-day feasts of honor, in which they fete their poorer rural relations, who provide labor and rice for these ceremonies. This situation is very similar to that described for the Toraja by Toby Volkman, Feasts of Honor (Urbana: University of Illinois Press, 1985).
} 


\section{History on the Ethnic Culture Page}

The past, the present, and the future are constructed in ethnically charged terms on SIB's ethnic culture page. However, there is no single consensus among writers there about the nature of time and the social worlds associated with its various periods. Two very different sorts of historical pieces are available on the Page, often placed in juxtaposition. Consequently, readers must shift between diverse historical perspectives as they move from one type of story to another.

The first type of historical writing on the page has close ties to nationalistic articles found in other sections of the paper. Upbeat, even boosterlike accounts of "this current age of National Development" are one of this Medan newspaper's main types of stories. They are printed on the front page and throughout each issue and deal with such topics as new hospital construction, home economics education projects in the villages, and the dedication of development projects, such as hydroelectric dams or new sewer systems. Some promotional, heavily nationalistic stories also appear on the ethnic culture page, typically in articles about how efforts to "preserve" a glorious Batak past can be used in the national government's campaign to increase international tourism in North Sumatra. In this type of piece, the present and the purportedly even more developed, more Indonesian future are the loci of greatest social worth; the past, a Batak place, is valuable mostly as a storehouse of old customs and village sites that can be rediscovered, refurbished, documented in cultural detail, and then presented to a largely non-Batak tourist market. Some of these articles also praise the Batak old days as a source of cultural richness (similar to the archipelago's other ethnic pasts) out of which the nation of Indonesia has been built, in line with its motto, Bhinneka Tunggal Ika (Unity from Diversity). In addition, a closely related type of story offers readers engaging narrative summaries of "old Batak legends," about ancient clan origin times, but then frames these tales within "true history," which writers associate with their own national era. Often these clan origin narratives, in this type of rendition, are presented in condescending tones as amusing stories and bits of Batak cultural tradition, suitable for folkloristic collection in this present age of national development. The similarity of this type of writing to that found in the Ministry of Education and Culture's Inventory of Ethnic Cultures series is obvious.

Alongside this genre of nationalistic journalism that so devalues and oversimplifies a Batak past is the ethnic culture page's other main sort of historical writing: unapologetic, much more straightforward accounts of clan origins, miraculous heirlooms, and sacred bark books, all presented largely on their own terms without any heavyhanded effort to place them within a national, present-day, or future-oriented context. These stories also often stress the cultural richness of the Batak past but use such comments to validate that ethnic heritage per se, not any national purposes to which those traditions might be put.

The authors of these articles are often special guest correspondents from the various Batak societies (with an occasional Niassian writing about that island culture). Sometimes it is obvious from the text that the authors are publishing their works for the first time. These writers are retired civil servants, Protestant ministers, school teachers, and college lecturers. Occasionally, SIB will assign one of its regular reporters or stringers to cover a Batak heritage event such as a clan club gathering. ${ }^{17}$ Many times these articles too will be written in

${ }^{17}$ For example, see "Raja Sonak Malela's Clan Descendents Hold Annual Party in Palembang," SIB, February 7. 1976, p. 5. 
forthright, factual terms without any major literary nods to the presence of the Indonesian nation or the "greater validity" of the present day over a Batak past.

An examination of several typical articles of each of these two main types will show the nature of their historical imagery more clearly and will also highlight the ideological tension along this particular plane of the ethnic culture page.

The first series of pieces to be considered lauds the up-to-date nation over a rich but outmoded Batak past. Articles of this type consistently strike the same theme that SIB's editors stress on page two of many issues. There, inside a black-rimmed box, are old archive photographs ("Pictures from Tempo Doeloe") of Batak village life during Dutch colonial times. The grainy black and white photographs generally depict Toba, Karo, or Simelungun Batak dressed in homespun, pounding rice with old-fashioned wooden mallets, weaving textiles, or setting off to adat rituals in their ceremonial finery (that is, in such decorations as leaf crowns and ulos, ritual textile cloaks). These pictures offer a diverting tatter of the Batak past set within the much larger, more serious-toned newspaper, with its reports of new irrigation projects, new school buildings, and new skyscrapers in Jakarta. The Batak peopling these photographs inevitably appear backward in such a context amid SIB's panoply of stories on modern Indonesia.

The most flagrantly reductionistic sort of article on ethnic history stresses the tourist attraction potential of old Batak or Niassian tradisi (the word sometimes used in SIB in place of Indonesia terms). This same sort of article sometimes appears elsewhere in the paper in an occasional tourism section.

One such piece was published in SIB's ethnic culture page on November 4, 1976, as part of a series entitled "A Week in South Tapanuli." Reported by regular staff writer Michael Pasaribu, the story was called, "Many Historical Remains in South Tapanuli Are Falling Apart." A subhead went on to report, "The Typical Salak Fruit Farm Yields Only Rp. 6000 a Month." Indeed, the stress throughout the piece was on the monetary value of both orchards and Batak traditions and their role in national development.

The article began, "When one considers the great number of historical remains in the forms of temples, statues, and stone inscriptions found in the districts of Padangbolak, Baruman Tengah, Barumun, Siabu, Panyabungan, Batang Toru, Sipirok, Padangsidimpan, Dolok and Saipar Dolok Hole (all remains now scheduled to be fenced in as tourist objects), there is a clear need for spurring economic development in the capital of Padangsidimpuan to support tourism." Accompanying the story were photographs of the fourteenth- or fifteenth-century Tantric temple at Portibi (South Tapanuli's main prehistoric ruin, long nearly fallen to rubble). Pasaribu went on to report comments from the local Cultural Affairs official from the Ministry of Education and Culture: If the central government would only develop and protect South Tapanuli's old temple ruins these structures "would surely attract both domestic and foreign tourists." The reporter avers that the South Tapanuli tourist objects are the equal of those in the Toba area; he also quotes South Tapanuli's Bupati administrator as boasting that the Portibi temple hails from the same period as Java's Candi Kalasan. Much of the rest of the article reads rather like a transcript of a government press release (e.g., "According to preservation plans, at the very latest at the beginning of 1977, a survey team from Jakarta will come in to inspect the temples and other historical remains in South Tapanuli."). In other sections the reporter editorializes that the subprovince's capital city should have better tourist accommodations if its officials hope to keep visitors overnight. Then, the last half of the article deals with government-sponsored development projects in South Tapanuli, such as irrigation works and bridge repair programs. 
There is no mention in any of this of the people who may have built the old temples or their possible connections to the Angkola and Mandailing people who live in the subprovince today. In fact, the words Angkola, Mandailing, and Batak are not used at all in the story, although the great majority of South Tapanuli residents are from those two subsocieties. The newspaper's technique here of eclipsing the ethnic units in a vocabulary of county districts and subprovinces echoes the national government's own preference for categorizing these areas and peoples in national terms. In this particular subprovince such vague geographical categorization schemes obscure great classification disputes about how best to describe the Angkola Batak and the Mandailing. Many of the latter, whose home villages are located near Panyabungan and Kotanopan, say they are not Batak at all. Mandailing were among Tapanuli's earliest migrants to Sumatra's East Coast plantation belt around the turn of this century; in Deli, numerous Mandailing dropped their diagnostically Batak clan names in order to blend in with local Muslim Malay society, after discovering that the category "Batak" suggested to Deli residents that the immigrants were pig-eating rustic infidels. Over the last fifteen years, however, some urban Mandailing are rediscovering their Batak roots and reattaching themselves to clans. Angkola also sometimes eschew the Batak category, for fear they will be associated with the Toba Batak (generally considered brusque, rough, and overly competitive, by their supposedly more refined southern neighbors).

To return to SIB articles with a nationalistic slant, a nother similar story on the April 11, 1976, issue's tourism page was headlined, "Using Batak Traditions for the Development of Tourism." This piece was reprinted on the May 22, 1976, ethnic culture page. In this long article, the author, Drs. B. A. Simanjuntak (a lecturer in anthropology and sociology) advocated the resuscitation, as it were, of certain pre-Christian Toba Batak village rituals, such as boat dedications. These would be used as lures to attract international tourists to North Sumatra. Simanjuntak argued that the Bataks had always been deeply religious and that fact would impress visitors in much the same way that Bali's religious heritage fosters tourism on that island. He explains:

When we cast our eyes towards Bali, we find pictured before us Bali and its people whose traditions (tradisi) truly strike wonder in our hearts. Now, we may not know how to truly evaluate that tradition in any deep way. But, because the international world has come to witness it, we people from within the country also come to value the beauty of that tradition quite highly.... This tourist incentive lures the populace toward a level of consciousness that leads them to quit simply neglecting our traditions. . . . The problem we encounter in this matter is the possibility of there being difficulties in bringing the traditions back to life once again. This is because of the following situation: there are already many, many people who have just left behind some of the traditions, and consider them useless in this age of progress.

Simanjuntak goes on to pinpoint certain Toba rituals-seen as bits of tradition-which can be resurrected for the tourist market.

Simanjuntak's understanding of Batak traditions as commodities to be sold on an international tourist market is obvious, but beyond that it is also interesting to note his total avoidance of the ethnic designation "Toba Batak" in this article. He is dealing exclusively with Toba pre-Christian rituals, not Angkola, Karo, or Dairi ones, but he does not acknowledge the fact that Toba is only one ethnic subsociety of several. Rather, he consistently oversimplifies the several Batak lands as a Toba domain and implicitly defines the Batak past as a Toba era-all without using the word Toba. This approach is typical of many of SIB's stories on the area's tourist potential. 
One additional article illustrates a last important technique in defining historical time in a way that trivializes the various Batak pasts. This particular piece treats Simalunguan Batak myths about clan history as fanciful legends. Framed in that way, the myths are presented to readers as amusing but unbelievable folk stories that a modern newspaper public would surely not mistake for true history. The article is entitled, "A Legend and True Tale about the Ancient Origins of the Names Mount Batu Nanggar and Serbelawan."18 The writer portrays himself as a serious seeker of historical truth; he compares different legends to see which has the most validity, realizing that all the Simalungun tales he is dealing with are unsophisticated village fictions. He gives greatest credence to a name-origin story told to him by a seventy-two-year-old adat chief. This circumstance lends a light, entertaining tone to the origin story:

In a friendly manner Tuan Dolok Batu Nanggur related the tale to the writer, the tale regarding the ancient origin of Mount Batu Nanggar and Serbalawan-a rendition which took more than three hours.

"Your arrival is quite fitting and appropriate," he said, starting in. [Note: the old man was the last surviving repository of the story.] It is known that in the past the Mount Batu Nanggar area was called Naga Lintang. The ones who were rajas in the Naga Lintang area were from the Sinaga clan. When the Sinaga clan held power in Naga Lintang there happened to come there a wayfaring bachelor from Nagasaribu-Seribudolok, from the Purba clan. He stayed in Naga Lintang after marrying a Sinaga girl, the daughter of the raja of that region.

A lengthy and charmingly told legend follows at this point, about a princess busy with her weaving work who teases a passing sorcerer into conjuring a fountain of water out of thin air.

The overall impression readers get from this article is that the Simalunguan landscape is associated with a multitude of hoary old stories that, when critically approached, may yield some small bits of true information about how past generations came to name mountains, rivers, and villages.

The articles and advertisements surrounding this piece reinforce the notion that Simalungun legends are entertainment forms. To the page's lower right are graphically attractive ads for pop music cassettes by Diana Yusuf and Jimmie Manopo and for a tape drama called "A Pensioner's Son," by the Toba Batak singer Anthon Na70 (i.e., the clan called Napitupulu [pitupulu means 70 in Toba]). To the lower left is a short notice of an upcoming performance of Aristophanes' Lysystrata by an ethnically mixed children's theater troupe in Medan. Below this is another piece, headlined, "Growth of the Traditional Arts in Transmigration Project Is Highly Gratifying." With the juxtaposition of such articles and ads, old Simalunguan tales about ancient ancestors in origin times are reduced in political scope even further to emerge as one very small part of a world collection of old stories about distant eras used now for diversion.

Standing in marked contrast to these articles are three representative pieces much more sympathetic to the Batak heritages as serious forms of historical knowledge. The first article offers readers an unadorned, unapologetic, unreinterpreted clan origin story. The author, who is unnamed, uses none of the framing devices so evident in the piece about Simalungun name origins. The story is entitled, "The History of the Nadapdap Clan in Sigumpar."19 The

${ }^{18}$ SIB, November $22,1980, \mathrm{p}$. 7. This was a special religion and culture page.

${ }^{19}$ SIB, February 7, 1976, p. 5. 
first several paragraphs indicate how closely the Indonesian prose style stays to Toba genealogical myth formats (i.e., the narrative relies on heroic figures, supernatural plot lines, and simple but evocative images):

Ompu Patubinbin was born in Djandjimatogu. He had two sons, that is to say: $O$. Patulonlan and Pamahat.

Patulonlan was exceedingly adept at breaking and riding horses. He had been given a red stallion by his father. Upon this horse he had traversed many places.

At that time wars between villages often occurred but Patulonlan wasn't afraid of being captured, abducted or murdered by anyone in the villages he visited.

The narrative continues in this vein through $O$. Patulonlan's marriage and the establishment of a village for that couple's descendants, "which is named Lumban Nadapdap and nowadays is also named Sigumparjae." That phrase ends the article, with no mention of tradisi or tourism.

An equally straightforward item on the same page reports the discovery of an heirloom dagger in a sacred grove in the Simalunguan area. The mystical elements of the story (for instance, the participants discover the dagger's whereabouts via a dream) are not denigrated as unbelievable. Nor is the heirloom identified as a tourist object. Rather, the discovery is handled as a straight news item. The headlines and several typical paragraphs ran as follows:

Heirloom Dagger Discovered in the Pematang Sidamanik Valley in Simalungun

- Thought to Be Buried for Hundreds of Years

-Discovered by a Fortuneteller

At the end of last January '76, an heirloom dagger was discovered in a ravine near a large tree in Pematang Village, an old village in Sidamanik Simalunguan. The dagger was discovered in a hole after a hole 1.5 meters deep was dug not far from the big tree trunk, known to be a haunted tree.

According to the information available, before the discovery of the dagger, a dukun diviner-healer living in Kerasaan Village in Bandar District had a certain dream. In his dream an old person comes up to him, saying that an ancient heirloom would have to be sought out. In this dream it was said that this object's location would be near a large tree, between a red palm sugar tree and a hardwood tree located in the Pamatang Sidamanik valley. Later, this portent was indeed fulfilled; it was activated by Pak A. Damanik and his family. They employed magic formulas, for by happenstance A. Damanik was a diviner. Once the hole had been dug in the earth after dark, in accordance with the portent, the birds and monkeys of the forest sent up a great clattering and chattering as if to signify the fact that the object in question would definitely be found.

The rest of the article continued this recitation of mystical events in a straight reporting style.

A third story (from the August 21, 1976, ethnic culture page) offers a pronounced Angkola reading of much the same subject matter treated in less flattering terms in Michael Pasaribu's "Many Historical Ruins in South Tapanuli Are Falling Apart." This article was written by the Padangsidimpuan novelist S. Baya and was entitled, "Are There Connections Between the Harahap Clan and the Historical Remains in South Tapanuli?" The author is from the. Harahap clan himself and works as a mid-level civil servant in the subprovincial office of the Ministry of Education and Culture; he writes novels for young people set at 
various periods of the revolution and the postindependence era. ${ }^{20} \mathrm{He}$ also contributes occasional free-lance pieces like this one to Medan newspapers; these stories deal with Angkola adat, village customs, and prehistory. The latter is handled in this particular August article as the generalized precolonial period. That was a time, Baya suggests, when great stone temples were built throughout South Tapanuli, all placed in intriguing proximity to centers of Harahap clan strength. He writes:

When we look at the old, old villages built and occupied by the Harahap clan in South Tapanuli, we notice a unique thing which makes us want to know about their historical connections. Because, almost each and every one of these villages contain historical remains, for instance biara-biara [old temples], statues, or at the very least old tombs decorated with art.

Now, why would that be so? is the question. Could this just be by happenstance?

As a direction for viewing this, we can focus our attention on a certain old village called Portibi....

This village is the remains of a Harahap clan kingdom which hundreds of years ago was a very great and important one. Around the ruins of the former Portibi kingdom can be found many historical remains, such as temples [biara], statues of people, of animals and so on and so forth....

When the shape of the Portibi temples is considered carefully, it is as if their shape is halfway between Hindu influence and Buddhist influence. Now, here is our opinion; a bit regarding this Portibi temple. We can try to investigate a bit about the meaning of the word "Portibi." In the South Tapanuli local language, Portibi means "the world," continent, or the earth. And, in the Sanskrit language we can say "Pertiwi." So, the pronunciation of Pertiwi can be assimilated with Portibi.

S. Baya goes on to suggest that it could have been Hindu immigrants who gave Portibi its name, or "at least (Portibi) might have once been under the domain of a Hindu Kingdom." He notes further that many Portibi residents even today have the sharp facial features that suggest Indian blood. Presenting himself as a careful amateur historian, Baya goes on to caution readers that no one should jump to conclusions without firm documentation.

In this serious-toned account, note how Baya marshalls the techniques of modern historiography to pursue his suspicion of an Indian link to Harahap clan history. He further buttresses his claims for Harahap clan importance by noting that Indonesians in general "came from India" and that they entered the archipelago via the Straits of Malacca. If Indians did live in early South Tapanuli, then, that would make the Angkola Batak ancestral to the Javanese and Balinese as an earlier, Indic-influenced civilization. One will see related attempts to rank Indonesian ethnic groups into a hierarchy of antiquity in SIB stories that deal with budaya, or culture, to be examined. But first, I suggest a short look at the ethnic culture page's treatment of social structure in provincial and national ethnic groups.

\section{Human Society on the Ethnic Culture Page}

A tension similar to that found in SIB's articles on history is also evident in the ethnic culture page's many stories describing the social systems of the various Batak peoples and

\footnotetext{
${ }^{20}$ Some of his books include Si Breok, (Bandung: Rosda, 1985); Mereka yang Dihiar, (Bandung: Rosda, 1985); Bukan Sekadar Gila, (Bandung: Rosda (1985); and Malam yang Mendebarkan, (Bandung: Rosda, 1985). He very self-consciously chooses to write his books in the national language, although he is quite fluent in Angkola Batak; from evidence of my interviews with him in 1986-1987 S. Baya sces himself as an Indonesian writer not just a Batak one.
} 
their Sumatran neighbors, the Niassians and the Gayo-Alas. One range of descriptive and sometimes overtly analytical, social sciencelike pieces portrays these societies as having extremely complex social structures that trace their origins to prenational, precolonial times. These intricate social systems (including, for instance, abstruse systems of kin terms and elaborate multiple-family households) are generally celebrated in this type of article for their complexity. Writers report that such social organizational intricacy demonstrates the refinement and high level of cultural advancement associated with these societies.

Juxtaposed to these lengthy, often lavishly illustrated laudatory articles on Sumatran societies are shorter, simpler pieces on Javanese high culture: its gamelan orchestras, its puppet plays, its court dances. SIB's editors seem to be promoting Sumatran societies as fit companions or even competitors for Java. The latter tends to be represented on the pages of $S I B$ via its palace arts, whereas the Sumatran societies demonstrate their excellence and human advancement through the many convolutions of their social systems. ${ }^{21}$

In contrast to these congratulatory and even smug accounts of Sumatran social systems is a second range of more negative articles about the Batak and nearby societies. This set of stories typically describes a local society's "sistim sosial" through constant reference to the organizational structure of the Indonesian nation, which becomes the touchstone for determining the ultimate worth of the ethnic social organizational feature at hand. For instance, a long piece on the Karo traditional house published on the ethnic culture page of December 6, 1976, describes each "hearth" household unit within the traditional, highpeaked adat house. Each of these family units corresponds to one of the major marriage alliance or political categories of Karo village society (for example, the wife-givers of the house owners, their wife-receivers; the family priest). A complete adat house, is therefore, a miniature, complete Karo social universe. But, the reporter of this December 1976 piece goes on to translate each of these Karo hearth categories into their supposed Indonesian national equivalents: there is, the author Ngasup Singarinbun writes, a Protokol (chief of protocol) for the house, a doctor (i.e., the traditional priest), and an intelligence bureau (his translation of the Karo household unit, Peninggol-Ninggol, or "the Listener" to enemy war secrets). This article treats Karo house architecture in generally positive terms but the overall impression readers get is that this sector of ethnic culture needs point-by-point explication in terms of the national language and in relation to the major bureaucratic units of the national culture.

Another article on a nearby Batak ethnic culture placed directly below this one on Karo houses illustrates a related theme: Indonesian cultural preeminence over the smaller ethnic traditions that the nation subsumes. This story highlights the central government's purported obligation to save vulnerable, decrepit ethnic traditions from disappearance.

Simalunguan Culture Totally Disappears in the Jorlang Hataran and Girsang Sipangan Bolon Regions.

- Because of this, the DKSS Siantar Simalungun immediately sends sympathy gifts.

P. Siantar. After the second day of the first Simalunguan Arts Week held 29-5-76 in Siantar, two of the 17 county districts (Jorlanghataran and Girsang Sipangan Bolon) had still not sent a contingent to the finals in the National Building in Siantar.

Because of this, the Bupati's office of the subprovince of Simalunguan greatly regretted the situation, to the point that they were forced to order the Simalungun Arts Council (the DKSS) to immediately dispatch sympathy gifts to those areas. It is said that Simalunguan culture in these two areas has totally vanished. Accordingly, the Sima-

21 This may help explain the great attention paid to the asymmetrical marriage alliance system and to kinship terminology in the Batak adat guide literature. These domains are especially arcane and complex. 
lunguan subprovincial government immediately issued a stern threat to the Education and Culture office which had failed to protect and develop Simalungun culture in these two areas. This was done in light of the fact that Simalunguan is one of the Tourist Projects for North Sumatra and in light of the fact that Simalungun culture must be nurtured, protected, and developed as best as possible. ${ }^{22}$

It is interesting to note that his same ethnic culture page has another article about "saving" vulnerable, wayward populations from cultural loss. This piece, on North Sumatran prostitutes, was placed opposite to the Simalunguan story. The headlines read:

Asahan SubProvincial Government Readies Receiving Center for Prostitutes in Cinta Pamai Buntu Pane.

- Their Mental State to Be Cultivated So They May Be Reintegrated into Society.

The paternalistic bias of such articles is obvious but one can look at a contrasting piece in more detail to see how Batak "social organizational complexity" is sometimes celebrated by SIB's special contributors. In such articles, Batak society is portrayed as vigorous rather than vulnerable and as "socially complete" rather than deficient.

The argumentative piece cited in the introduction to this article is an apt representative of this genre. The story was entitled, "It's the Conservation of Batak Adat That's Important, Its Modernization Isn't Necessary, for It's Been Modern Since the Past." 23 This article by special contributor Gr. Mula Pitara Siahaan was a heated response to an earlier piece by Professor P. Sormin on the "social functions" of the major adat relationships such as wifegiver/wife-receiver alliances. Gr. Mula begins his essay by asserting that Batak adat (by which he means Toba adat) was established by the distant ancestors in formal councils of rajas. He reports in a peevish tone that a Western researcher had recently commented to him that Batak adat seems to vary a good deal from region to region. This is not really so, Siahaan responds: the naive researcher had apparently been recording local people's misinterpretations of what were actually unchanging verities. Adat has splintered into regional varieties, he acknowledges, but researchers must take care not to record these as Batak traditions per se. The latter reflect a splendidly complicated social order made up of marriage alliance ties among the three-stones-on-the-hearth ${ }^{24}$ partners and the housepost partners. These are, respectively, a man's lineage mates, his wife-receivers, and his wife-givers and, secondly, his mother's brother, his pariban (members of other lineages who share his same wife-givers), his various nephews, and his circle of friends.

The author discusses these interlocking sets of alliance partners at length via a barrage of proverbs taken from Toba-language adat oratory. He also discusses the adat's many gift payments and debts as well as chieftan organization. Batak adat emerges as unusually confusing and abstruse in this account: a challenge to the reader, and a credit to its village representatives. Outside SIB, there is also a large Toba, Simelungun and Angkola print literature on adat rules and rituals that takes the same tack. Numerous adat guidebooks on such topics as "how to negotiate a brideprice" eulogize the supposed complexity and extreme subtlety of old village ways for ordering human social life.

22 SIB, June 12, 1976, p. 5.

23 SIB, December 4, 1976, p. 5.

${ }^{24} \mathrm{Or}$, in Batak, the dalihan na tolu. This stones-on-the-hearth image is the central one for referring to marriage alliance and clanship loyalties in both oratory and everyday conversation. 


\section{Ethnic Cultures}

$S I B$ offers its faithful readers a wide universe of ethnic cultures to sample from both Indonesia and other countries. Describing these cultures on the page is a small part of the much larger media enterprise of constructing the idea of ethnic culture as folkways. I will return to this larger perspective in the conclusion but first will give an account of how "culture" is used in this section of SIB.

Cultures close to home are given heaviest play on the ethnic culture page. Readers are offered weekly doses of information on Toba Batak village dances, Nias stone sculpture, Karo kinship, Angkola orators, and so on. Indeed, these North Sumatran cultures are presented in just such terms, as composites of folk dances, old customs, social sub-systems, and ancient sayings. As noted, cultures located outside the province, such as the Javanese and Balinese cultures, make very occasional appearances on the page, often via their court dances and gamelan orchestras. More distant cultures, such as those of West Germany, France, and China, (which appear on the page even less frequently) are also represented through their high culture arts, such as their famous oil paintings. Indonesian national culture is never presented directly on SIB's ethnic culture page, although its cultural standards are invoked in some articles as a measure of worth for evaluating some aspect of Batak or Niassian culture. In addition, ethnic cultures on the page are implicitly and sometimes quite baldly ranked into a hierarchy of more and less advanced cultures in terms of the civilization level they have attained. Nearly all regular staff reporters and special contributors employ this rhetoric of ranked, folkloristic, composite ethnic cultures. That is, it seems that in this third domain of budaya, or culture, so conceived, SIB leaves little room for the sort of political maneuvering apparent in history and social organization. Once writers enter the portals of ethnic culture discourse, apparently they must accede to the notion that Batak culture and Niassian culture are a bit out of date in relation to the developing national culture and are subordinate to certain other higher, finer cultures. The only rhetorical mechanism for escaping these constraints seems to be SIB's occasional articles on old speech forms and the old Batak syllabary. In stories (often, schoolbooklike lessons) about the old village sayings and the Batak letters, writers can exult over this one sector's cultural richness. This renders the ethnic languages fit competitors to the national language.

Consider two short, overtly educational articles on language, both written in this vein. The first offers readers a plan for studying the old Batak script at home. Written by special contributor Ompu ni Marhulalan Sihombing Nababan, the piece is called "The Batak Letters and their Ancient Origins." 25 This installment was lesson number 16 in a long series on the Toba script. Readers are introduced to the proper way to denote the sound "ng" in Toba writing. This small point adds to the readers' previous knowledge of the signs of the syllabary and allows them to write a large variety of new words. The piece follows a lesson format; the image of written Toba that emerges from the article is one of orderliness, clean logic, and, again, cultural intricacy. This sector of Toba culture is presented as part of a larger "curriculum of Toba culture," which the reader can presumably acquire by studying the page on a regular basis.

In this same article the author then goes on to relate an engaging episode from a Toba myth about how a young hero named $\mathrm{Si} A \mathrm{ji}$ Gara first learned the old letters from a diviner, Datu Aji Gorga. This story provides the script with a mythic pedigree (one not cast as "old

${ }^{25}$ SIB, August 24, 1979, p. 5. 
folktales" but presented as genuine history). The narrative also provides the lesson itself with an added measure of cultural content and seriousness.

Placed next to this article on the same page is a similar article entitled, "About the Nias Local Language." This one was contributed by Faogomane Telaumbanua, a secondary schoolteacher from Nias's capital Gunung Sitoli. This article proceeds at a rapid clip through descriptions of the various aspects of the Nias language's phonetic system. Readers learn about the unique features of Niassian (e.g., "There never is a consonant that isn't followed by a vowel. ... We only encounter this custom in a few languages outside Indonesia, for instance Malagasy, in the Caucasus, in Raretonga, and in Samoa, even through Niassian never really spread that far"). Then, the author goes on to assert that the new spelling system used in writing the national language is not appropriate to the task of writing Niassian, for that language has more sounds that the modern spelling system can accommodate. The writer ends with a call to safeguard the purity of the Niassian language and its linguistic rules. As was the case with the Batak letters, the Niassian language is pictured here as a worthwhile, finely detailed, distinct, eminently logical subsector of an ethnic culture. Indonesian culture, mentioned in this instance in terms of the national language, is cast in a negative light.

SIB's tendency to define culture via the arts and language is important to note. To the right-hand side of this article is a short piece on "The Modern Wayang Golek," about the efforts of a Sundanese troupe to use this form of drama as a da'wah medium for spreading Islam. Above this is a photograph of a Javanese woman surrounded by three men from the Australian Arts Council's subcommittee on music; the caption informs readers that the council also deals with traditional crafts, the plastic arts, and television and film. Such a juxtaposition of articles on puppet plays, international arts councils, Batak script lessons, and apologia for the Nias language leaves readers with an image of a world filled by cultures consisting mainly of arts and literatures, available to outsiders as leisure time entertainment forms or as home-study lessons.

The adat worlds of the Batak societies and Nias are construed in the paper in much this same light. Outside $S I B$, in actual social life in villages, adat is experienced primarily as a network of everyday obligations and debts based on marriage alliances and celebrated periodically in "life-affirming" community rituals. Adat debts to other families and lineages are onerous; "keeping adat" demands hard work and much patience, which is needed for dealing with recalcitrant relatives who refuse to contribute their share to communal feasts. Moreover, many rural people experience adat as an especially tension-filled arena of their lives, where vituperatively competitive family factions fight over meat distributions and land inheritance. Adat, in fact, is a subject of some dread. On the ethnic culture page, however, readers discover an adat of art forms. A typical article in this vein went (in summary) as follows:

The Toba Batak House

by D. Nadapdap

'What's hidden under water can be guessed, What's in a person's heart: Who knows?"

the saying puts it.

The soul [hati] of the Toba Batak people is well portrayed in the construction of their houses, as follows:

1. The Toba Batak people first conceive a plan before constructing a house.... 
2. A cooperative, mutual-aid spirit [is evident too in the house architecture].

3. [So too is] the spirit of respecting each other....

4. And an open heart....

5. A spirit of: one for all and all for one, one-soul, one-heart, one-feeling. ...

6. An artistic spirit. The walls and so on are full of carvings. This shows that the Toba Batak soul is the soul of artists.

This article was illustrated with a striking photograph of a magnificent Toba traditional house. This particular structure had been moved from its original site to a location in Lumbannabolon that was accessible to tourists.

When adat's competitive nature is acknowledged, social dissent issues are quickly domesticated by being handled as minor matters the reader can learn to deal with via SIB's helpful adat lessons. Many articles written in this vein portray "traditional village life" as predominantly amicable and orderly.

Alongside such stories, $S I B^{\prime}$ 's editors often place articles whose rhetoric reminds readers that Indonesian ethnic cultures, and in fact the world's cultures, are ranked into a hierarchy of backwardness and advancement. The following piece from the ethnic culture page of June 26, 1976, illustrates this assumption, pervasive in the paper, that cultures can be tagged as relatively more or less civilized. The author of this piece, it happens, was offended by an earlier story that dealt too harshly with the Sim Sim:

An Opinion on:

"The Sim Sim People Out in the Rural Regions Are Still Backward"

In regard to the story in SIB's North Sumatra edition of 29 May 1976. . . . with the above-mentioned title, I happen to be a native son of that people and I feel called to give the following opinion:

In principle, as a native son of the area I feel pride in reading the news story because with the information provided surely social experts will begin to direct more attention to the area, and with that they'll be able to perfect and up-grade the village society described, which does represent one of the very most backward ones left.

The author goes on to object to the use of the ethnic designation Sim-Sim, writing that this population is really a Pak-Pak group (a Batak society west of Lake Toba). Further, he notes that they do not really live in huts covered with forest leaves but in small houses topped with thatch. This is due to their poverty, he notes; the Sim Sim are so poor they cannot even go into the nearby market town regularly.

How does Indonesia, as a nation, appear on the ethnic culture page? The subject is not directly addressed on the page, but Indonesia hovers as a constant presence just beyond the individual articles and their subject ethnic cultures. The rest of SIB is largely devoted to Indonesia and its economic development. When the nation is mentioned on the page it tends to be evoked as a legal framework within which Batak or Nias adat is embedded. In addition, Indonesia is sometimes mentioned via descriptions of National Heroes such as $\mathrm{Si}$ Singamangaraja XII. Two sample articles will show these approaches.

A July 31, 1976, article by Ny. Ir. B. Sitepu Sidaburar S.H. offers an energetic attempt to reinterpret Toba Batak elopement-style marriage in a national Indonesian legal framework. The piece was entitled "Culture Letter from Jakarta: Mangalua or Eloping Is Not Really Eloping as Viewed from the National Indonesian Marriage Law Now Enacted." The author attempted a systematic, erudite comparison of Toba adat law on elopement with national 
marital law. Toba adat is treated as "village customs" whereas the Indonesian legal code is presented as the modern framework within which customs are set.

A final article links Batak adat to national culture via Toba's national hero, the warriorking SiSingamangaraja XII. This May 17, 1980, article concerns the planting of a small banyan tree in the Toba town of Tigaraja in commemoration of an anniversary of the old king's death. Accompanied by a photograph of the sapling behind an impressive protective gate, the story is headlined, "Linkages between the Banyan Tree and Batak Culture." The article begins with a note about the ancient origin of the fervent Batak interest in this magical, benevolent, protective tree. The author, Harryson Manurung, cites Toba proverbs that evoke the banyan's wide-branched shape; he reports that the trees were once planted near each village to shelter the nobles and to forestall disputes; he notes the use of banyan leaves as part of warriors' costumes. He laments the fact that banyan lore is fast disappearing and then goes on to remark, optimistically, that combined government and private efforts to commemorate the heroic career of SiSingamangaraja XII is having the side benefit of encouraging a renewed interest in the tree for ritual purposes. A large party of provincial government officials has accompanied SIB's publisher, readers find, to Tigaraja to plant the special banyan tree to commemorate the old hero's death. The article ends by evoking an image of delegations of old Batak chiefs conferring with SiSingamangaraja himself. But, the chiefs are associated here with the present-day government officials: "The planting of the banyan tree acted as a climax for the ceremony commemorating the demise of National Hero SiSingamangaraja XII, a ceremony normally held in Prapat but just this one time celebrated with great festivity in the Ancient-Home-Village. The official committee viewed all of this ritual activity. It will also be recalled that during Sisingamangaraja XII's life Tigaraja (was the site where he met) with the local rajas."

The author of this passage attempts, at least, to embellish local officialdom with links to a heroic Toba past and to an age of glorious fighter-kings. Unspoken although surely evident to many readers is the fact that the banyan tree is Golkar's (the central government's political party) symbol as well as an old Toba icon. Articles of the sort illustrated by this story (particularly in SIB's long-running series of SiSingamangaraja XII pieces) attach boosterish images of old Batak chieftains to figures from the Indonesian governmentlinking national development plans and the bureaucracy to ancient Toba times, places, sacra, and leaders. Little room is left in such accounts for assertions of an independent Batak culture.

\section{Conclusion}

As Benedict Anderson has noted, 26 the newspaper is "a form of imagining": imagining particular kinds of social worlds in print, imagining specific time frameworks, and imagining a peculiarly modern sort of reader. Every day, a new edition of the paper appears, filled with ephemeral items reporting "late news" events from different corners of the globe. Holding the newspapers in their hands, the readers are left with the task of drawing this panoply of reports from diverse cultural locales into a single social framework (a multicultural world) and a coherent time framework (the immediate past, accessible to readers in the here and now). In addition to assigning this central role to the informed readers, the newspaper's status as a mass commodity means that readers must be lured into buying issues every day-thus the proliferation of entertaining feature stories, which cushion the paper's

26 Benedict Anderson, Imagined Communities: Reflections on the Origin and Spread of Nationalism (London: Verso, 1983). See especially pp. $37-40$ on newspaper literacy. 
hard news items and amuse or titillate the reader. SIB clearly participates in all these aspects of international journalism.

Anderson makes another insightful point ${ }^{27}$ about newspapers as a form of print: they are closely bound to another genre of writing, modern novels, and cannot be fully understood in isolation from the history of fiction. Indeed, in any full account of North Sumatran newspaper writing it would certainly be necessary to follow this lead and document the connections between both forms of fictive writing and the similar social universes they have offered North Sumatran readers since the 1920s.

Stopping short of that ambitious task, I conclude by moving beyond the study of print per se into the larger question of the politics of culture in contemporary Indonesia as a realm of debate between ethnic minority societies like the Batak and the Indonesian nation. Today, mass media forms of various types seem to be devoted in important part to that dialogue between local society and national society.

Two recent articles by anthropologists Toby Volkman and Janet Hoskins ${ }^{28}$ are useful here in putting $S B^{\prime}$ 's ethnic culture page into such a broad perspective. Volkman reports that the Sa'dan Toraja have been active "culture creators" in recent encounters with international tourists (revising their adat funerals, for instance, in light of European tourist demands for the exotic). The Toraja have also rethought their ceremonial culture in a politically astute way to give them increased prestige over inner Indonesian societies such as Bali. In other words, the Toraja have been anything but passive partners in the Indonesian nation's attempts to extend its cultural hegemony down to the village level throughout the island chain. Hoskins finds a similar cultural resilience and resourcefulness in Kodinese attempts (in West Sumba) to elevate an old headhunter warrior figure from their past to the status of national hero. In Kodi, local people do not simply accept central government dictates about history but actively rethink the past in local, ethnic minority terms. The rhetorical disputes seen on SIB's ethnic culture page seem to be evidence of much the same phenomenon happening in North Sumatra in the print sector of mass culture. Inquiries into whether or not similar debates are taking place with similar vigor in other regional newspapers would seem to be a useful area of study.

A final issue also merits attention in the study of Indonesia's contemporary politics of culture: SIB's preocupation with the artistic and folkloristic aspects of ethnic cultures may be part of a larger pattern in which adat worlds of village ceremony and moral life are being transformed into art, for entertainment's sake, directed toward audiences from outside the home ethnic culture at issue. This larger pattern is well underway in the Batak cultures ${ }^{29}$ where ritual oratory is being redefined as folklore, where ritual textiles are emerging as collectors' items, and where wooden sculptures (once used as ancestor effigies) are displayed in the goverment museum in Medan as primitive art. SIB's ethnic culture page may well be just one of the public culture's vehicles for presenting and debating this more general conceptual reformulation of the archipelago's many cultures.

\footnotetext{
27 Ibid., pp. 37-40.

28 Toby Volkman, "Great Performances: Toraja Cultural Identity in the 1970s," American Ethnologist 11 (1) (1984): 152-69; and Hoskins, "Headhunter as Hero," pp. 605-22.

${ }^{29}$ See, for instance, R. Griffin Coleman, "Pakpak Marriage Ritual as Cultural Performance Ritual as Cultural Performance: Use and Meaning of the Term Adat," in Cultures and Societies of North Sumatra, ed. Rainer Carle (Berlin: Reimes, 1987), pp. 309-27, and idem, "Sipirok Batak Wedding Speeches-Adat or Art?" in Art, Ritual and Society in Indonesia, ed. Edward M. Bruner and Judith O. Becker, Ohio University Center for International Studies, Athens, Ohio, Southeast Asia Series no. 53, pp. 30-61.
} 
